\title{
Factors that Cause Mental Health Problems in Covid-19 Nurses
}

Riza Arisanty Latifah ${ }^{1}$, Rully Annisa ${ }^{2}$

${ }^{1}$ Nursing Science Program, Universitas Muhammadiyah Cirebon, Indonesia

${ }^{2}$ Nursing Science Program, Universitas Muhammadiyah Purwokerto, Indonesia

\begin{tabular}{l} 
ARTICLE INFO \\
\hline Article history: \\
DOI: \\
10.30595/pshms.v2i.231 \\
Submitted: \\
December 6, 2021 \\
Accepted: \\
January 21, 2022 \\
Published: \\
January 26, 2022 \\
\hline
\end{tabular}

Keywords:

Age, Covid-19 Nurse, Gender, Marital Status, Mental Health Problems

\begin{abstract}
Covid-19 is an infectious disease that is endemic in all countries in the world, including Indonesia. Nurses who are frontline health workers are significantly at risk of experiencing Covid-19 transmission. This causes several mental health problems such as anxiety, stress, insomnia, excessive fear and even depression. So researchers need to study further what factors can cause mental health problems in COVID-19 nurses. This research is quantitative research with a correlation approach. This research was conducted at Gunung Jati Hospital, Cirebon. The sample in the study amounted to 60 nurses. The sampling technique was purposive sampling, with inclusion and exclusion criteria determined by the researcher. Data collection techniques through google forms using the Self Reporting Questionnaire (SRQ). The statistical test used is the Chi-Square Test using SPSS. The results of this study indicate that there is a relationship between age $(\mathrm{p}=0.000)$; Gender $(\mathrm{p}=0.003)$, marital status $(\mathrm{p}=0.002)$, on mental health problems for Covid-19 nurses. There is a relationship between age, gender, gender and marital status, with the mental health of COVID-19 nurses.
\end{abstract}

This work is licensed under a Creative Commons Attribution 4.0 International License.

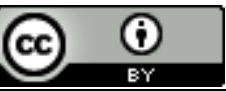

Corresponding Author:

Riza Arisanty Latifah,

Nursing Science Program, Universitas Muhammadiyah Cirebon, Indonesia

Email: rizaarisanty@umc.ac.id

\section{INTRODUCTION}

Coronavirus disease - 19 (COVID-19) is an infectious disease first discovered in Wuhan, Hubei Province, China, at the end of 2019. This disease has attracted the attention of the Indonesian people and even internationally. The reason is that in Indonesia itself, the number of positive cases of Covid-19 patients is increasing. Not only patients, but the virus also attacks several nurses who often have direct contact with positive COVID-19 patients. It causes nurses to be exposed to the virus.

A preliminary study conducted at the Gunung Jati Hospital, Cirebon City in October 2019, recorded 39 health workers who tested positive for COVID-19, some of whom were nurses. It causes concern both for the Nurse herself and other nurses who have worked in the same place. In addition, the mental health of the nurses at the hospital experienced problems, such as anxiety, stress, fatigue, fear, and even insomnia. It can happen if there is a lack of support from all parties, lack of time to rest, and minimal skills to increase fatigue, work stress, and anxiety, which has an impact on decreasing the quality of services provided. [1] [2]

According to the research on the Severe Acute Respiratory Syndrome (SARS) and Middle East Respiratory Syndrome (MERS) plague, Frontline health workers report experiencing high levels of stress that result in post- traumatic stress or often referred to as Post Traumatic Stress Disorder (PTSD). The results of a preliminary study conducted by researchers provided an SRQ questionnaire that 9 out of 10 nurses experienced signs of mental health disorders such as difficulty sleeping, difficulty in 
making decisions, decreased appetite, and indigestion. [3] These are signs of an emotional problem. During the Covid-19 outbreak, research in several countries examined the factors that affect the level of anxiety in health workers, namely nurses, namely long working hours, an increasing number of patients, lack of social support, fear of transmitting COVID-19 to closest family friends. [4]

Other research many health workers who treat COVID-19 patients experience a psychological burden, especially female nurses. [5] It is supported by research conducted by [6]. Based on the relationship test, there was a relationship between age, gender, marital status, availability of PPE, and nurses' knowledge of the anxiety experienced by nurses while taking care of Covid-19 patients. So based on the background of the problem, the researcher wants to study more about the factors that can cause mental health problems in nurses at the Gunung Jati Regional Hospital.

\section{RESEARCH METHOD}

This research is quantitative using a cross- sectional design. The variables used in this study were health workers as the dependent variable and the independent variables as the causative factors, namely age, gender, and marital status. The population in this study were nurses who were kept in the prevention, handling, and care of Covid-19 patients in the hospital isolation room and storage at the Gunung Jati Regional Hospital. Sampling technique determination using total sampling. Of the 72 nurses who were targeted in the research subjects, there were 60 online-based returns. The respondents' criteria used as subjects in this study were active nurses aged 21 to 50 years, and they became respondents. [7]

This research questionnaire uses online media. Namely, Google Forms is divided into two parts, the first part is demographic data, and the second part is the Self Reporting Questionnaire (SRQ). Questionnaires were distributed for 15 days. The analysis was carried out using chi-square to determine the relationship between the variables of age, sex, and marital status on the variables of mental health problems Nurse.

\section{RESULT AND DISCUSSIONS \\ 3.1 Result}

Table 1. Analysis of factors causing mental health problems in Covid-19 nurses $(\mathrm{n}=60)$

\begin{tabular}{|c|c|c|c|c|c|}
\hline \multirow[t]{2}{*}{ Variable } & \multicolumn{4}{|c|}{ Mental Health Problems n (\%) } & \multirow[t]{2}{*}{$p$} \\
\hline & \multicolumn{2}{|c|}{ Disturbance } & \multicolumn{2}{|c|}{ No Disturbance } & \\
\hline \multicolumn{6}{|l|}{ Gender } \\
\hline Male & 8 & $(13,3)$ & 16 & $(26,6)$ & 0,003 \\
\hline Female & 29 & $(48,4)$ & 7 & $(11,7)$ & \\
\hline \multicolumn{6}{|l|}{ Age } \\
\hline$<30$ Years & 21 & $(35)$ & 11 & $(18,3)$ & 0,000 \\
\hline$>30$ Years & 16 & $(26,7)$ & 12 & $(20)$ & \\
\hline \multicolumn{6}{|l|}{ Marital Status } \\
\hline Not Married Yet & 4 & $(6,7)$ & 15 & $(25)$ & 0,002 \\
\hline Marry & 33 & $(55)$ & 8 & $(13,3)$ & \\
\hline
\end{tabular}

Table 1 shows that most nurses experience mental health problems $(61.7 \%)$, while those who do not experience disorders $(38.3 \%)$. Based on the results of the gender characteristics, $60 \%$ of the respondents were female, with $(48.4 \%)$ female respondents experiencing mental health problems or disorders. Based on age, almost all ages experienced infections, namely age <30 years (35\%) and age $>30$ years $(26.7 \%)$. Meanwhile, most respondents with married levels experienced disturbances based on marital status, namely $(55 \%)$. From the results of the Pearson chi-square test, there is an influence between gender $(\mathrm{p}=0.003)$, age $(\mathrm{p}=0.000)$, and marital status $(0.002)$ on nurses in treating Covid-19 patients.

\subsection{Discussions}

Coronavirus disease - 19 (COVID-19) is an infectious disease first discovered in Wuhan, Hubei Province, China, at the end of 2019. The reason is that in Indonesia itself, the cases of positive Covid-19 patients are increasing. Not only patients, but the virus also attacks several nurses who often have direct contact with positive COVID-19 patients. It causes nurses to be exposed to the virus and makes other nurses worry, resulting in mental health problems such as anxiety, stress, or even depression. 
Based on the results of this study, we obtained data that there is a relationship between mental health problems of nurses and several causative factors such as gender, age, and marital status. Gender in this study correlates with the occurrence of mental health problems for nurses who treat COVID-19 patients. It can be seen from the $\mathrm{p}$ value $=0.003$ where $48.4 \%$ of respondents of the female gender have experienced mental health problems or disorders. It is supported by research by [5] ,many health workers who handle COVID-19 patients experience psychological burdens, especially female nurses.

The age category in this study influences nurses' health problems, which is seen from the value $(\mathrm{p}=0.000)$, where the average age of nurses caring for Covid patients is impaired, namely age $<30$ years $(35 \%)$ and age $>30$ years $(26,7 \%)$. According to Puspanegara research (2019), there is a relationship between late adulthood and coping mechanisms with anxiety $(\mathrm{p}=0.005)$. Most of the ages 21 to 45 years experience anxiety disorders.

The research conducted by [7] obtained almost the same results as this study. Namely, there was an influence between age on the anxiety of nurses caring for COVID-19 patients. It can be seen from the value $(\mathrm{p}=0.030)$, where almost all ages 30 years $(39.1 \%)$ or $>30$ years $(26.1 \%)$ experienced mild anxiety. During this Covid-19 pandemic, health workers feel pressured and worried about increasing tension in carrying out their duties. [7] [12]

The psychological response experienced by health workers to this infectious disease pandemic is increasing because it is caused by feelings of anxiety about their health and the spread to their families. [9] [11] This study explains a relationship between marital status and mental health problems for nurses who treat COVID-19 patients $(\mathrm{p}=0.002)$. The results of the research support it by Fadly [7] Most of the health workers in the study were married to 83 people $(72.1 \%)$, while those who were not married were 32 people $(27.8 \%)$.

Based on the research results above, this is one of the factors they experience anxiety because when treating positive patients with Covid-19 or conducting examinations on people who have Covid-19 symptoms. Nurses are worried that they will transmit the Covid-19 coronavirus to their families [10] [13] They also feel stigmatized because they feel themselves in contact with patients infected with the virus. This study indicates that the status of health workers who have families with anxiety tend to have a more significant influence than unmarried health workers $(\mathrm{r}=0.38 ; 95 \% \mathrm{CI}=$ $0.15-0.81)$.

\section{CONCLUSION}

This study indicates an influence between age, gender, and family status on nurses in charge of handling Covid-19 patients. Psychological responses experienced by nurses include decreased appetite, difficulty sleeping, difficulty in making decisions, and digestive disorders, so they need emotional support both from the institution where they work and their families at home.

\section{Acknowledgements}

We want to thank the Ministry of Research and Technology/National Research and Innovation Agency for facilitating and financing this research process.

\section{REFERENCES}

[1] Gao, Z., Xu, Y., Sun, C., Wang, X., Guo, Y., Qiu, S., \& Ma, K, “A systematic review of asymptomatic infections with COVID-19," Journal of Microbiology, Immunology and Infection, 2020.

[2] Cai, J., Sun, W., Huang, J., Gamber, M., Wu, J., \& He, G. "Penularan virus tidak langsung dalam klaster kasus COVID-19, Wenzhou, China, 2020," Penyakit menular yang muncul , 26 (6), 1343, 2020.

[3] Clark, A., Jit, M., Warren-Gash, C., Guthrie, B., Wang, H. H., Mercer, S. W., \& Checchi, F., "Global, regional, and national estimates of the population at increased risk of severe COVID-19 due to underlying health conditions in 2020: a modelling study," The Lancet Global Health, 8(8), e1003e1017, 2020.

[5] Lai, J., Ma, S., Wang, Y., Cai, Z., Hu, J., Wei, N., \& Tan, H, "Factors associated with mental health outcomes among health care workers exposed to coronavirus disease 2019" JAMA network open, 3(3), e203976-e203976, 2020.

[6] Fadly, F., Safruddin, S., Ahmad, A. S., Sumbara, S., \& Baharuddin, R. "Faktor yang Mempengaruhi Kecemasan pada Tenaga Kesehatan Dalam Upaya Pencegahan Covid-19," Jurnal Pendidikan Keperawatan Indonesia, 57-65, 2020.

[7] Nursalam, N. I. D. N., "Metodologi Penelitian Ilmu Keperawatan. Notoatmodjo.(2010). Metodologi Penelitian Kesehatan,” Jakarta: PT. Rineka Cipta, 2016. 
[8] Perlman, S., \& Netland, J, "Coronaviruses post-SARS: update on replication and pathogenesis". Nature reviews microbiology," 7(6), 439-450, 2009.

[9] Lai, J., Ma, S., Wang, Y., Cai, Z., Hu, J., Wei, N. \& Tan, H. "Factors associated with mental health outcomes among health care workers exposed to coronavirus disease 2019" JAMA network open, 3(3), e203976-e203976, 2020.

[10] Shanafelt, T., Ripp, J., \& Trockel, M., "Understanding and addressing sources of anxiety among health care professionals during the COVID-19 pandemic" Jama, 323(21), 2133-2134, 2020.

[11] Puspanegara, A, "Pengaruh Usia terhadap Hubungan Mekanisme Koping dengan Kecemasan Ketika Menjalani Terapi Hemodialisa Bagi Para Penderita Gagal Ginjal Kronik di Kabupaten Kuningan Jawa barat," Jurnal Ilmu Kesehatan Bhakti Husada: Health Sciences Journal, 10(2), 135-142, 2019.

[12] Pfefferbaum, B., \& North, C. S. "Mental health and the Covid-19 pandemic," New England Journal of Medicine, 2020.

[13] Raven, J., Wurie, H., \& Witter, S., "Health workers' experiences of coping with the Ebola epidemic in Sierra Leone's health system: a qualitative study," BMC health services research, 18(1), 251,2018. 